\section{International Journal of Research in Social Science and Humanities (IJRSS)}

DOI: http://doi.org/10.47505/IJRSS.2020.9115
E-ISSN : 2582-6220

Volume 1, Issue 3

Jul - Aug - 2020

\title{
Study of Quality Assurance in Examination Conduction and Administrative Effectiveness of Principals in Public and Private Secondary Schools in Niger State, Nigeria
}

\author{
Dr. Abossede Ayobola Igunnu \\ Department of Foundations \\ School of Education FCE Zaria \\ Nigeria
}

\begin{abstract}
The research was on a study of Quality Assurance in Examination Conduction and Administrative Effectiveness of Principals in Public and Private Secondary Schools in Niger State, Nigeria. To successfully accomplish the aim of the study, two research questions and hypotheses were raised and the descriptive survey research design was adopted for the study. The study utilized a population of twenty eight thousand, nine hundred and thirty eight $(28,938)$ principals and teachers in all the public and private schools in Niger state, Nigeria. Simple random sampling technique was used to select principals and 731 teachers who were used to study the principals. Data was collected using 'Measures of Quality Assurance and Administrative Effectiveness (MQAAEQ)', which was validated by experts in the subject area. The instrument was pilot tested with 43 principals using inter-rater reliability and the coefficient which was found to be $0.76-0.89$. Data collected were analysed using mean and Standard Deviation, onesample t-test and One-way ANOVA) Also, the Fisher's Least Significance Difference Test (LSD) was employed to determine the direction of mean differences. Findings revealed that there is a statistical significant influence of standard in examination conduct and adherence of students' admission goals in terms of effective teaching, effective principal teachers' relationship and effective supervision of instruction. It was recommended among others that the government should support principals to adhere to standard in examination conduct by availability and adequacy of facilities to enhance quality in examination conduct.
\end{abstract}

Keywords: Quality Assurance, Examination Conduction, Administrative, Effectiveness.

\section{BACKGROUND TO THE STUDY}

Education is seen as the backbone of any society irrespective of how underdeveloped it. For education to have quality all stake holders must put force together to enhance teaching and learning in the environment. This underscores the role of the teacher in promoting educational advancement. It is important to consider teachers as the building block of any institution. Thus, neglecting the place of the teacher in enhancing quality is as formulating baseless policies. It is also glaring that the teacher cannot function efficiently without the principals. This is because his roles and obligation is to foster quality in terms of effectiveness in the day to day administrative affairs.

This has made scholars like Imogie, (2014) to see education as an instrument per excellence for enforcing the right norms and values of the society.. It entails the totality of all skills, competences, attitudes and values which an individual acquires over time for survival and development of the society. It makes the individual to become useful assets for societal growth and development. Therefore, the quality of education is a product of quality assurance and a crucial determinant of the direction of its national development. This underscores the need for quality policy education by government of Nigeria at all levels which. It is a well known fact that in order to pursue quality instruction and students performance/productivity, it is important to have efficient control mechanisms put in place to achieve the set educational objectives which lies on the shoulders of the principals. It is the principals role to formulate quality administrative policies and practices that can enhance quality in teaching and learning coupled with total quality in the administrative affairs of the school.

According to Nwagwu, Ijeomaand Nwagwu (2004), maintaining quality is a product principals effectiveness in terms of quality teaching, availability and utilization of instructional facilities, teachers efficiency and proper examination delivery (Borahm \& Ziarati, 2010). This implies that the school principal is vested with the role of by academic and administrative duties to enhanced effectiveness in the school system. The National University Commission (2007) informed that qualities are the set standards needed by every school to enhance process and product of the school system. The role of maintain quality will promote 
standard and eradicate all forms of unethical practices in the academic environment. to this end, the principals administrative role is paramount to enhance academic success in the school environment.

In an empirical review by Osuji and Etuketu (2019) on School Administrators Quality Assurance Strategies for the Implementation of Curriculum in Junior Secondary School in Owerri Municipal, Imo State. The design of the study was a descriptive survey. Three research questions and three null hypotheses guided the study. The population of the study comprised 150 respondents drawn from 25 public and 25 private secondary schools. The sample of the study consisted of 150 school administrators which includes principals and vice principals (Academic and Admin). Questionnaires were used as instrument for data collection. The validation of the instrument was subjected to face validation by experts in measurement and evaluation. The reliability of the instrument was established using Cronbach alpha method of analysis with a reliability score of 0.764 ,descriptive statistics in order to answer the research questions, while z-test statistics was used to test the null hypotheses at 0.05 level of significance. The study discussed the quality assurance strategies such as monitoring, supervision and evaluation as employed by school administrators to enhance academic quality and performance effectiveness in the school system. The study also found that standard in examination conduct has a significant influence on administrative effectiveness. The study concluded that proper application of these strategies by school administrators could enhance and promote quality assurance in the junior secondary schools.

In another study Osakwe, (2016) study was concerned in Principals' Quality Assurance Techniques for Enhancing Secondary School Quality Education in the 21st in Abraka Delta state. Despite this laudable aim, the products of secondary schools are turned out half-baked becoming liability than assets due to poor standards resulting from the defective educational system. Hence, this aim would be achieved through employing principalsee quality assurance techniques in secondary schools. Hence, this paper discussed principalse quality assurance techniques for enhancing secondary school quality education in the $21^{\text {st }}$ century in Delta State, Nigeria. The study found that quality assurance in terms standard procedure in examination conduct has a significant influence on administration of secondary schools. It also made some useful recommendations to include adequate funding, provision of personnel.

Quality assurance assists in providing academic excellence on the part of the principal, teachers as well as students who are expected to be the beneficiary of the teaching/learning process. Thus, the need quality enhance academic excellence in school and promote effectiveness. Ibrahim and Al-Tanaji. (2012) informed that quality deals with the process and product of all impute and output of the school that can foster effectiveness and promote achievement in the school. Fadokun (2005) sees quality as the process of being efficiency in meeting of students' admission goals, fostering standards in the educational environment and promoting success in all areas of learning

Total quality assurance in the educational environment deals with the accomplishment of the educational needs and aspiration of the school by putting in place all the limited resource and enhancing its proper utilizations for quality results in the school system (Fadipe, 2009). Effectiveness can successfully be enhanced by total utiliseation of all the available resources both human and material resources to enhanced job effectiveness on the part of the principals. It I a glaring fact that the principal serves as a watch dog in the school as such it is his/her responsibility to ensure that quality is maintained. In school where quality assurance is lacking, there is bound to be shortage in productivity and performance will be affected (Rice, 2010).It should be noted that the sole aim of the school principal is to enhance quality assurance in the school setting by following all the rules and regulations as entrenched in the teachers' conditions of service. To accomplish this there is need to strictly adherence to students' admission policy. Birzea, Cecclini, Krekand-Vrkas (2005) noted that for quality assurance to be maintained, there should be a clearly and well defined specification of purpose by identifying specific gaps to be filled in the organization. These gaps are areas identified as need in the organization and they may include issues like poor building, lack of seats for students, in adequate teaching and learning resources like library, laboratory, instructional materials availability and utilization and so forth. providing these need can foster effectiveness by he school principals which is also capable of promoting effectiveness. (Birzea et al, 2005). This simply means that for quality to be maintained, secondary education must adherence to students admission policy as a strict measure to maintaining educational standard in secondary schools in Niger state, Nigeria.

Study by Nwite (2017) where concerned in assessing the quality assurance practices in secondary schools in Enugu State Nigeria. Six specific purposes, six research questions and six null hypotheses guided the study. The descriptive survey research design was adopted for the study. The population of comprised 291 principals of public secondary schools and 92 school evaluators in the Ministry of Education totaled 383. The entire population served as the sample. The instrument used for data collection was structured questionnaire titled "Assessment of Quality Assurance Practices in Secondary Schools in questionnaire "AQAPSSQ". The reliability of the questionnaire was established using a trial test method on a group of 20 principals and 10 evaluators from Ebonyi State gave a reliability co-efficient of 0.77 . The data collected were analyzed using mean and standard deviation to answer the research questions while t-test statistics was used to test the null hypotheses at 0.05 alpha. The findings of the study revealed among others that: provision of infrastructural facilities, adherence to students admission goals influence 
administrative effectiveness of public and private secondary schools in recruitment of qualified teachers, secondary school curriculum implementation and effective leadership management are quality assurance practices in secondary schools in Enugu State. Based on these findings, some recommendations were made among which are: that methods of recruitment of teachers should be on merit basis not on quota system which was filled by unqualified teachers. Secondly, government, its agencies and other private bodies should be involved in improving staff welfare in secondary schools.

Calleb and Agundele (2011) study focused on effectiveness of student admission policies in public and private universities in Kenya. Data was collected from a sample of 502 university students using a structured questionnaire. It was found that public universities did not have the necessary national and ethnic diversity of students; however, majority of students were studying courses of their preferences. Faith based private universities considered religious faith of students before accepting or rejecting applications for admission. It was found that public universities admitted students of higher grades than private universities. It was recommended that the government formulates policies regulating student admissions to guarantee transferability of student grades across universities, acceptable diversity of students and exemption rules for admission in public and private universities.

Arikewuyo (2004) views quality in education to be judged by both its ability to enable the students performs well in standard examinations and relevance to the needs of the students, community, and the society as a whole. The author finally concluded that quality serves as determination of gradations based on standard of excellence beneath which a mark of inferiority is imposed or adduced and above which grades of superiority are defined. However, quality assurance is related to quality control, but it function in a rather proactive manner in the sense that quality control serves as series of operational techniques and activities used to fulfill that requirement are met. While, quality assurance goes beyond that, because it extends the focus from outcomes or outputs to the process which produces them. This means that to foster quality in education the principals must shown high level of technicality in maintaining quality assurance in the academic environment in order to achieve the stated aims and objective of the school. It is a well documented fact that schools without quality measured tends to produce graduates who cannot withstand the taste of time in the academic environment. The major problem is on the labour market where these set of graduate will find themselves at the end of their stay in school.

\section{RESEARCH PROBLEM}

The issue of poor quality assurance in the educational sector has attracted series of worries by stakeholders, parents and government have attracted worries over the need to ensure improvement in the quality of the education system and thus the focus on school administration which is saddled with the responsibility of providing leadership. In most secondary schools, there are issues bordering of principals administrative effectiveness in terms of resources management and maintenance of quality admission process in the school. Most principals do not understand the basic role expected of them in the school they are assigned to head. This may be due to lack of effectiveness on the part of the principal. Also, there have been a total outcry on the quality of student product in secondary school, most students who are believed to have graduated from secondary school cannot even read nor construct a simple sentence after graduation. it is alarming to say that these set of student end up reading lucrative courses in the university in-spite of these lapses. The overall issue is on the society where they will end up working. The blame is on the school as most parents and stakeholders put bulk of the blame on the teachers and principals for lack of quality in the educational system. As most parents feel that administrative effectiveness has been compromised in most public and private schools in Niger state. The problem of this study is: what is the measures of quality Assurance and administrative effectiveness of public and private secondary schools in Niger State, Nigeria?

\section{PURPOSE OF THE STUDY}

The main purpose of the study was to examine quality assurance in examination conduction and administrative effectiveness of principals in Public and Private Secondary Schools in Niger State, Nigeria

1. To examine the influence of standard in examination conduct on administrative effectiveness of public and private secondary schools in Niger State, Nigeria.

2. How does adherence of students admission goals influence administrative effectiveness of public and private secondary schools in Niger State, Nigeria

\section{RESEARCH QUESTIONS}

The study utilized to research questions viz:

1. To what extent does standard in examination conduct influence administrative effectiveness of public and private secondary schools in Niger State, Nigeria? 
2. What is the influence of adherence of student's admission goals on administrative effectiveness of public and private secondary schools in Niger State, Nigeria?

\section{RESEARCH HYPOTHESES}

$\mathrm{Ho}_{1}$ : There is no significant influence of standard in examination conduct on administrative effectiveness of public and private secondary schools in Niger State, Nigeria in terms of effective teaching, effective principal teachers' relationship and effective supervision of instruction.

$\mathrm{Ho}_{2}$ : Adherence of students' admission goals does not significantly influence administrative effectiveness of public and private secondary schools in Niger State, Nigeria in terms of effective teaching, effective principal teachers' relationship and effective supervision of instruction.

\section{METHODOLOGY}

The study adopted the descriptive research design with a population of 28,938 principals and teachers in public and private schools in Niger state, Nigeria. The study adopted the survey research design and the simple random sampling technique was used to select principals and 731 teachers who were used to study the principals, from this figure, only 718 was used in the final study. Data was collected using 'Measures of Quality Assurance and Administrative Effectiveness (MQAAEQ)', which was validated by experts in the subject area. The instrument was pilot tested with 43 principals using inter-rater reliability and the coefficient which was found to be $0.76-0.89$. Data collected were analysed using mean and Standard Deviation, one sample t-test and One-way ANOVA) was used to test the two hypotheses raised and Fisher's post hoc comparison was used to determine the mean differences obtained from the omnibus ANOVA..

\section{RESULTS AND DISCUSSIONS}

The result of the study is presented below.

Hypothesis one: There is no significant influence of standard in examination conduct on performance effectiveness by administrators of public and private secondary schools in Niger State, Nigeria. The independent variable of this study is standard in examination conduct while the dependent variable is administrative effectiveness categorized in terms of prompt release of result, effective teaching, effective principal teachers' relationship and effective supervision of instruction. To test this hypothesis, the one sample t-test was used as presented in Table 1

TABLE 1: One-Sample t-statistics of the influence of standard in examination conduct on administrative effectiveness of public and private secondary schools in Niger State, Nigeria

\begin{tabular}{lccllll}
\hline $\begin{array}{l}\text { administrative } \\
\text { effectiveness }\end{array}$ & $\mathrm{N}$ & Mean & $\begin{array}{l}\text { Std. } \\
\text { Deviation }\end{array}$ & $\mathrm{T}$ & Df & p-value \\
\hline effective teaching & 718 & 15.3092 & 3.51332 & 98.50 & 510 & .000 \\
\hline
\end{tabular}

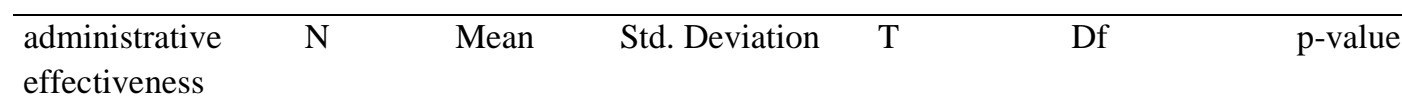

effective principal

$\begin{array}{lllllll}\text { teachers } & 718 & 16.7646 & 4.27820 & 105.001 & 717 & .000\end{array}$

relationship

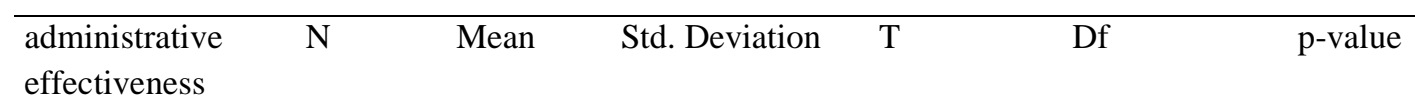

\section{effective}

$\begin{array}{llllll}\text { supervision } & \text { of } 718 & 16.4861 & 3.98802 & 110.770 & 717\end{array}$

instruction

$* \mathrm{p}<.05$ 
It is obvious from Table 1 that the p-value for administrative effectiveness in terms of effective teaching, effective principal teachers' relationship and effective supervision of instruction are .000, .000 and .004 which are less than the chosen alpha of .05. Thus, the null hypothesis is rejected. This implies that there is a significant influence of standard in examination conduct on administrative effectiveness of public and private secondary schools in Niger State, Nigeria in terms of effective teaching, effective principal teachers' relationship and effective supervision of instruction.

\section{Hypothesis Two}

Adherence of students' admission goals does not significantly influence administrative effectiveness of public and private secondary schools in Niger State, Nigeria in terms of effective teaching, effective principal teachers' relationship and effective supervision of instruction. The major independent variable in this hypothesis is adherence of students' admission goals measured in term of high moderate and low, while the dependent variable is administrative effectiveness categorised in terms of effective teaching, effective principal teachers' relationship and effective supervision of instruction. To test this hypothesis, one way ANOVA was employed because the independent variable has three categories (high, moderate and low), while the dependent variable was measured continuously. The result is presented in Table 2.

TABLE 2: Result of one-way ANOVA of adherence of students' admission goals on administrative effectiveness

\begin{tabular}{|c|c|c|c|c|c|}
\hline Effective teaching & Sum of Squares & df & Mean Square & $\mathrm{F}$ & p-value \\
\hline Between Groups & 770.949 & 2 & 385.475 & 22.313 & .000 \\
\hline Within Groups & 12352.272 & 715 & 17.276 & & \\
\hline Total & 13123.221 & 717 & & & \\
\hline $\begin{array}{l}\text { effective principal } \\
\text { teachers' relationship }\end{array}$ & Sum of Squares & df & Mean Square & $\mathrm{F}$ & p-value \\
\hline Between Groups & 667.916 & 2 & 333.958 & 19.171 & .003 \\
\hline Within Groups & 12455.306 & 715 & 17.420 & & \\
\hline Total & 13123.221 & 717 & & & \\
\hline $\begin{array}{l}\text { Effective supervision of } \\
\text { instruction }\end{array}$ & $\begin{array}{l}\text { Agricultural } \\
\text { production } \\
\text { Guinea corn }\end{array}$ & of & Mean Square & $\mathrm{F}$ & p-value \\
\hline Between group & & 2 & 338.269 & 19.432 & .001 \\
\hline Within Groups & 12446.683 & 715 & 17.408 & & \\
\hline Total & 13123.221 & 717 & & & \\
\hline
\end{tabular}

$* \mathrm{p}<.05$

Table 2 revealed that the p-value for effective teaching, effective principal teachers' relationship and effective supervision of instruction is $.000, .003$ and .001 which were all less than the chosen alpha of .05 thus the null is rejected. This implies that the adherence of students' admission goals has a significantly influence administrative effectiveness of public and private secondary schools in Niger State, Nigeria. The rejection led to a Post-Hoc comparison to determine the mean differences in Table 3.

Table 3: Fisher LSD of the influence of adherence of students' admission goals on administrative effectiveness

\begin{tabular}{|c|c|c|c|c|c|c|}
\hline \multirow{2}{*}{$\begin{array}{l}\text { Adherence } \\
\text { students' } \\
\text { admission } \\
\text { goals }\end{array}$} & \multirow{2}{*}{$\begin{array}{l}\text { of Effective } \\
\text { teaching }\end{array}$} & \multirow{2}{*}{$\begin{array}{l}\text { Mean Difference } \\
(\mathrm{I}-\mathrm{J})\end{array}$} & \multirow[t]{2}{*}{ Std. Error } & \multirow[t]{2}{*}{ Sig. } & \multicolumn{2}{|c|}{$95 \%$ Confidence Interval } \\
\hline & & & & & Lower Bound & Upper Bound \\
\hline \multirow{2}{*}{ High } & Moderate & $-2.22649^{*}$ & .35081 & .000 & -2.9152 & -1.5377 \\
\hline & Low & -.27001 & .41209 & .513 & -1.0791 & .5391 \\
\hline \multirow{2}{*}{ Moderate } & High & $2.22649^{*}$ & .35081 & .000 & 1.5377 & 2.9152 \\
\hline & Low & $1.95648^{*}$ & .41972 & .000 & 1.1325 & 2.7805 \\
\hline \multirow{2}{*}{ Low } & High & .27001 & .41209 & .513 & -.5391 & 1.0791 \\
\hline & Moderate & $-1.95648^{*}$ & .41972 & .000 & -2.7805 & -1.1325 \\
\hline
\end{tabular}


International Journal of Research in Social Science and Humanities (IJRSS), Vol .1(3)，July-Aug - 2020

\begin{tabular}{|c|c|c|c|c|c|c|}
\hline $\begin{array}{l}\text { students' } \\
\text { admission } \\
\text { goals strategies }\end{array}$ & $\begin{array}{l}\text { principal } \\
\text { teachers' } \\
\text { relationship }\end{array}$ & $(\mathrm{I}-\mathrm{J})$ & & & Lower Bound & Upper Bound \\
\hline \multirow{2}{*}{ High } & Moderate & $-2.17516^{*}$ & .35667 & .000 & -2.8754 & -1.4749 \\
\hline & Low & -.71844 & .40923 & .080 & -1.5219 & .0850 \\
\hline \multirow{2}{*}{ Moderate } & High & $2.17516^{*}$ & .35667 & .000 & 1.4749 & 2.8754 \\
\hline & Low & $1.45672^{*}$ & .40581 & .000 & .6600 & 2.2535 \\
\hline \multirow[t]{2}{*}{ Low } & High & .71844 & .40923 & .080 & -.0850 & 1.5219 \\
\hline & Moderate & $-1.45672^{*}$ & .40581 & .000 & -2.2535 & -.6600 \\
\hline Adherence of & Effective & Mean & Std. Error & Sig. & 95\% Confiden & Interval \\
\hline $\begin{array}{l}\text { students' } \\
\text { admission } \\
\text { goals }\end{array}$ & $\begin{array}{l}\text { supervision of } \\
\text { instruction }\end{array}$ & Difference $(\mathrm{I}-\mathrm{J})$ & & & Lower Bound & Upper Bound \\
\hline \multirow{2}{*}{ High } & Moderate & $-2.12590^{*}$ & .35389 & .000 & -2.8207 & -1.4311 \\
\hline & Low & -.44222 & .41240 & .284 & -1.2519 & .3674 \\
\hline \multirow{2}{*}{ Moderate } & High & $2.12590^{*}$ & .35389 & .000 & 1.4311 & 2.8207 \\
\hline & Low & $1.68368^{*}$ & .41240 & .000 & .8740 & 2.4933 \\
\hline \multirow[t]{2}{*}{ Low } & High & .44222 & .41240 & .284 & -.3674 & 1.2519 \\
\hline & Moderate & $-1.68368^{*}$ & .41240 & .000 & -2.4933 & -.8740 \\
\hline
\end{tabular}

*. $\mathrm{p}<0.05$ level.

It is evident from Table 3 which revealed the result for Adherence of students' admission goals does not significantly influence administrative effectiveness in terms of effective teaching has a significant mean difference in the category of high and moderate (-2.22649), while for adherence of students' admission goals does not significantly influence administrative effectiveness on effective principal teachers' relationship has a significant mean difference in the category of high and moderate (-2.17516) and for adherence of students' admission goals does not significantly influence administrative effectiveness on effective supervision of instruction has a significant mean difference in the category of high and moderate (-212590). This implies that the mean differences in the three category lies on high and moderate.

\section{DISCUSSIONS OF OUTSTANDING RESULT}

The finding from the 718 respondents used in the study drawn from the administered questionnaire revealed that there is a significant influence of standard in examination conduct on administrative effectiveness of public and private secondary schools in Niger State, Nigeria. Thus, there is need for all school authorities to ensure total quality in the system which will foster unity and accountability in the educational system. The finding agrees with Osujiand Etuketu (2019) whose study find that quality assurance strategies such as monitoring, supervision and evaluation as employed by school administrators for achieving quality education in secondary schools. This study also found that standard in examination conduct has a significant influence on administrative effectiveness. The finding also agree with Osakwe, (2016) study found that quality assurance in terms standard procedure in examination conduct has a significant influence on administration of secondary schools.

The findings of hypothesis two from the 718 respondents used in the study revealed that there is a significant influence of adherence of students admission goals on administrative effectiveness. As quality assurance is the judicious utilization of all the available human and material resources to maintain standards in academic environment. The present finding is in agreement with Nwite (2017) whose finding revealed among others that: provision of infrastructural facilities, adherence to students admission goals influence administrative effectiveness of public and private secondary schools in recruitment of qualified teachers, secondary school curriculum implementation and effective leadership management are quality assurance practices in secondary schools in Enugu State. Also in agreement, Calleb and Agundele (2011) study found that quality assurance is significantly related to principals administrative effectiveness and efficiency in the school.

\section{CONCLUSION}

In conclusion, the need for quality assurance in our schools cannot and should never be compromised in any educational setting. This is based on the fact that if every available resources are put in place, it will promote and enhances excellence in the system. Thus, absence of quality can only be enhanced when the principal adhere to quality control in the administration of their duty. The present study informed that for quality to be maintained in secondary education all efforts must be put in place by all concerned in the educational environment in terms of administrative effectiveness in all areas of education. The study finally 
added that all the principles of management and administration should be utilised efficiently for enhanced and quality academic excellence in secondary schools in Niger State, Nigeria.

\section{RECOMMENDATIONS}

The following recommendation were drawn in the study

1. Government should support principals to adhere to standard in examination conduct through adequate funding and manpower requirement so that they will be build extra buildings to enhance quality in examination conduct.

2. There should be need for principals to enact laws that will guide teachers in adhering to quality in admission of students in schools so as to enhance quality in their administrative effectiveness.

\section{REFERENCES}

Arikewuyo, M. O. (2004). Effective funding and quality assurance in the Nigerian education system. Paper presented at the 1st National Conference of the Institute of Education, Olabisi Onabanjo University, Ago-Iwoye. January. pp 12-15.

Birzea, C., Cecchini, M., Krek, J., \& Vrkas V. (2005).Tool for Quality Assurance of Education for Democratic Citizenship in Schools. France, United Nations Educational, Scientific and Cultural Organization (UNESCO).

Borahan, N.G. \& Ziarati, R. (2010). Developing Quality Criteria for Application in Higher Education sector in Turkey. Totality Management, 13(7), 913- 720.

Calleb O G. \& Maureen A O. (2011). Admission Policies for Quality Assurance: Towards Quality Education in Kenyan Universities: Journal of Business and Social Science 2 ( 8), 123-127.

Fadokun, D.O. (2005). Personality characteristics and principal leadership effectiveness inEkiti State. Nigeria International Journal of Leadership studies, 6(2). 27-36.

Fadokun, J.O. (2005). Quality Control in Education. Management of Nigerian Education, Law, Structures, Responsibilities, Ondo: NIEPA.

Ibrahim, A. S., \& Al-Tanaji, S. (2012). Principals' leadership style, School performance and principals effectiveness in Dubai schools. International Journal of Research Studies in Education, 2(1), 41-54.

Imogie, (2014).The role of supervision in quality assurance. Paper presented at the Training Workshop for Inspectors of Education and Education Officers in Edo State at Bishop Kelly Pastoral Centre, Benin City.

NUC, (2006).Counting the Blessing of the Obasanjo Administration to the Nigerian University System.A Memo.

Nwagwu, N.A., Ijeoma, M.A., \& Nwogwu, C.C. (2004).Organization and administration of education: Perspective and Practices. University of Benin, Benin City.

Nwite, O. (2017). Assessment of Quality Assurance Practices in Secondary Schools in Enugu State Nigeria Nwite Onuma and Nkiru Patricia Okpalanze. Middle-East Journal of Scientific Research 25 (8), 1695-1714.

Osakwe, R. N. (2016). Principals' Quality Assurance Techniques for Enhancing Secondary School Quality Education in the 21st in Abraka Delta state. Journa of Emerging Trends in Educational Research and Policy Studies (JETERAPS) 7(2), 176180.

Osuji, C. \& Etuketu, E.L. (2019). School Administrators Quality Assurance Strategies for the Implementation of Curriculum in Junior Secondary School in Owerri Municipal, Imo State. International Journal of Innovative Education Research 7(3), 101-119

Rice, J. K. (2010). Principal's effectiveness and leadership in an era of accountability: what research says. Centre for analysis of longitudinal data in Education research. 2010 November/December WAEC (wasscegce.examination.html).

The National University Commission (2007).A report from the Maryland teacher professional development advisory council. Retrieved July 9, 2019, from http://www.msde.maryland.gov/NR/rdonlyres/DF957230-EC07-AFEE-B9047FEB176BD978/20964/PDACReport6220 
International Journal of Research in Social Science and Humanities (IJRSS), Vol .1(3)，July-Aug - 2020 